\title{
A 100-year record of changes in organic matter characteristics and productivity in Lake Bhimtal in the Kumaon Himalaya, NW India
}

\author{
Preetam Choudhary, Joyanto Routh and Govind J. Chakrapani
}

\section{Linköping University Post Print}

\section{Tweet}

N.B.: When citing this work, cite the original article.

The original publication is available at www.springerlink.com:

Preetam Choudhary, Joyanto Routh and Govind J. Chakrapani, A 100-year record of changes in organic matter characteristics and productivity in Lake Bhimtal in the Kumaon Himalaya, NW India, 2013, Journal of Paleolimnology, (49), 2, 129-143.

http://dx.doi.org/10.1007/s10933-012-9647-9

Copyright: Springer Verlag (Germany)

http://www.springerlink.com/?MUD=MP

Postprint available at: Linköping University Electronic Press http://urn.kb.se/resolve?urn=urn:nbn:se:liu:diva-89515 


\title{
A 100-year record of changes in organic matter characteristics and productivity in Lake Bhimtal in the Kumaon Himalaya, NW India
}

\author{
Preetam Choudhary ${ }^{\mathrm{a}}$, Joyanto Routh ${ }^{\mathrm{b} 1}$, Govind J. Chakrapani ${ }^{\mathrm{c}}$ \\ aLimnology Department, Evolutionary Biology Centre, Uppsala University, \\ 75236 Uppsala, Sweden \\ ${ }^{\mathrm{b}}$ Department of Water and Environmental Studies, Linköping University, 58183 \\ Linköping, Sweden \\ ${ }^{c}$ Department of Earth Sciences, Indian Institute of Technology, Roorkee 247667, India
}

\begin{abstract}
Sediment variables total organic carbon (TOC), total nitrogen (TN), total sulfur (TS), as well as their accumulation rates and atomic ratios $(\mathrm{C} / \mathrm{N}$ and $\mathrm{C} / \mathrm{S})$, were studied along with stable isotopes $\left(\delta^{13} \mathrm{C}, \delta^{15} \mathrm{~N}\right.$, and $\left.\delta^{34} \mathrm{~S}\right)$, and specific biomarkers ( $n$-alkanes and pigments) in a 35-cm-long sediment core from Lake Bhimtal, NW India. The average sedimentation rate is $3.6 \mathrm{~mm} \mathrm{yr}^{-1}$, and the core represents a provisional record of $\sim 100$ years of sedimentation history. Bulk elemental records and their ratios indicate that sediment organic matter $(\mathrm{OM})$ is derived primarily from algae. In-lake productivity increased sharply over the last two decades, consistent with paleoproductivity reconstructions from other lakes in the area. An up-core decrease in $\delta^{13} \mathrm{C}$ values, despite other evidence for an increase in lake productivity, implies that multiple biogeochemical processes (e.g.
\end{abstract}

${ }^{1}$ Corresponding author: joyanto.routh@liu.se, Tel: +4613282272 
external input of sewage or uptake of isotopically depleted $\mathrm{CO}_{2}$ as a result of fossil fuel burning) influence the $\mathrm{C}$ isotope record in the lake. The $\delta^{15} \mathrm{~N}$ values $(-0.2$ to $-3.9 \%$ ) reflect the presence of $\mathrm{N}$-fixing cyanobacteria, and an increase in lake productivity. The $\delta^{34} \mathrm{~S}$ profile shows enrichment of up to $5.6 \%$, and suggests that sulfate reduction occurred in these anoxic sediments. Increases in total $n$-alkane concentrations and their specific ratios, such as the Carbon Preference Index (CPI) and Terrestrial Aquatic Ratio (TAR), imply in-lake algal production. Likewise, pigments indicate an up-core increase in total concentration and dominance of cyanobacteria over other phytoplankton. Geochemical trends indicate a recent increase in the lake's trophic state as a result of human-induced changes in the catchment. The study highlights the vulnerability of mountain lakes in the Himalayan region to both natural and anthropogenic processes, and the difficulties associated with reversing trophic state and ecological changes.

Key words: Paleoproductivity, Organic matter, Stable isotopes, $n$-Alkanes, Pigments 


\section{Introduction}

Nainital is a popular hill resort in the Kumaon Himalayan region of northwestern India. Mountain lakes in the region are a major source of drinking water and also serve as important venues for recreational activities. These perennial lakes are home to a rich collection of avian and aquatic life forms, and many unique and rare plants grow in their catchments (Sharma et al. 1982; Chakrapani 2002). As increasing numbers of tourists visit Nainital to escape the summer heat in the plains and enjoy the idyllic mountain setting, it stresses the limited resources in town, with respect to housing, transportation, food, and drinking water supply. This is evident from increasing levels of environmental pollutants in the atmosphere, surface water and aquifers, and soils in this region (Chakrapani 2002; Das 2005). For example, lakes in the Kumaon region have undergone changes during the last few decades that have affected water quality, increasing heavy metal content and algal productivity (Chakrapani 2002; Das 2005; Choudhary et al. 2009a, b). Remedial measures were undertaken by the local authorities (Kumar 2007), but were largely restricted to Lake Nainital, located in the heart of the city. It is feared that other lakes in the region, for which there are virtually no background data, will undergo negative changes that will be difficult to reverse.

Lakes in mountainous terrains are considered extreme environments because they are small and sensitive ecosystems that experience rapid flushing rates (Vreča and Muri 2006). These lakes respond quickly to natural or human-induced perturbations in their catchments. The effects of these perturbations are potentially recorded in sediments, which can be used for reconstructing past conditions over different timescales (Battarbee et al. 2002; Vreča and Muri 2006; Choudhary et al. 2009a, b). Preservation of sediment 
organic matter (OM) in these lakes is usually high (Vreča and Muri 2006; Choudhary et al. 2009a, b) because of multiple processes, including high productivity, rapid sedimentation, and anoxic conditions on the lake bottom (Meyers 2003). As a result, these organic-rich lacustrine sediments retain their original source signatures (e.g. $\mathrm{C} / \mathrm{N}$ ratio, specific biomarkers), and thus reflect environmental conditions at the time of deposition.

There are many reviews on applications of elemental and stable isotopes in paleolimnology (Kaushal and Binford 1999; Meyers and Teranes 2001; Meyers 2003). Total organic carbon (TOC) in lake sediments is a component of OM that escaped remineralization after deposition, and reflects depositional processes, OM sources, and long-term preservation issues. Likewise, total nitrogen (TN) and total sulfur (TS) have frequently been analyzed to understand post-depositional processes in lake sediments (Urban et al. 1999; Meyers and Teranes 2001). The $\delta^{13} \mathrm{C}$ values of algae and $\mathrm{C}_{4}$ plants are distinct, whereas there is little or no difference between carbon isotopic values of algae and terrestrial $\mathrm{C}_{3}$ plants (Meyers 2003). Stable $\mathrm{C}$ and $\mathrm{N}$ isotope values in lake sediments have also been used as indicators of aquatic productivity (Hodell and Schelske 1998; Brenner et al. 1999).

Biomarkers are complex lipid molecules that are unambiguous indicators of OM sources. They are useful for reconstructing paleoenvironmental conditions with respect to past vegetation and climate change (Meyers 1997, 2003). The hydrocarbon composition of most algae and photosynthetic bacteria is dominated by $n-\mathrm{C}_{17}$ alkanes (Cranwell et al. 1987). In contrast, vascular plants contain large proportions of $n-\mathrm{C}_{27}, \mathrm{C}_{29}$, and $\mathrm{C}_{31}$ alkanes in their epicuticular waxy coatings (Cranwell et al. 1987; Rieley et al. 1991). Ratios 
between $n$-alkane chains such as the Carbon Preference Index (CPI; Allan and Douglas 1977), indicate predominance of odd over even $n$-alkanes, and specify terrestrial OM sources and maturity. Similarly, the Terrigenous Aquatic Ratio (TAR; Bourbonniere and Meyers 1996) quantifies in situ algal versus terrestrial OM. Pigments are specific indicators of phytoplankton diversity and can be used to estimate aquatic productivity or biomass (Leavitt 1993; Bianchi et al. 2002). They have been used to identify siliceous algae and dinoflagellates (fucoxanthin), chlorophytes (lutein, pheophytin $b$ ), diatoms (diatoxanthin), dinoflagellates (peredinin), and cyanobacteria (echinenone, zeaxanthin).

Lake Bhimtal is one of the largest lakes in Nainital. In recent years, population has increased rapidly within the lake's catchment. As a consequence of rapid urbanization, and increased domestic and industrial wastewaters entering the lake from sewers and open drains, there has been pronounced deterioration in lake water quality (Chakrapani 2002; Das 2005). Very little, however, is known about the different sources of OM input into the lake, or the effects of external nutrient inputs on primary productivity and phytoplankton composition. The present study applied geochemical measures (elemental ratios, stable isotopes, and biomarkers) in sediment $\mathrm{OM}$ to explore the recent environmental history of Lake Bhimtal. Understanding the past and ongoing biogeochemical processes in these mountain lakes, which result from anthropogenic activities and/or climate changes, is vital for implementing restoration methods and sustainable management practices. We also compare the paleoenvironmental history of Lake Bhimtal with other mountain lakes in the Kumaon region (Chakrapani 2002; Das 2005; Choudhary et al. 2009a, b, 2010), and formulate general conclusions regarding the status of these vulnerable water bodies. 
Study area

Lake Bhimtal $\left(29^{\circ} 20^{\prime} \mathrm{N}, 79^{\circ} 36^{\prime} \mathrm{E}\right)$ is located at an altitude of $1,371 \mathrm{~m}$ above mean sea level in the Kumaon Hills (Fig. 1). The lake is $1.8 \mathrm{~km}$ long, $0.4 \mathrm{~km}$ wide, and has a maximum depth of $26.5 \mathrm{~m}$. The catchment area is $11.4 \mathrm{~km}^{2}$. The mean air temperature during summer is $28^{\circ} \mathrm{C}$, whereas in winter the mean temperature can be as low as $14^{\circ} \mathrm{C}$. The lake experiences monsoon rains during the months of July-September, and annual precipitation is $1,711 \mathrm{~mm}$. Lake Bhimtal formed as a consequence of tectonic activity, resulting from the uplift of sediments in the Tibetan and Indo-Gangetic plains (Valdiya 1988). The lake basin consists of metabasic rocks belonging to the Krol Formation, which is associated with quartzites, grits, conglomerates, phyllites, and metamorphic rocks.

\section{Materials and methods}

Sediment cores were collected from the deepest part of the lake in December 2004. A gravity corer was used to obtain two undisturbed sediment cores (BT 1 and BT 2), which were $55 \mathrm{~mm}$ in diameter and 35 and $38 \mathrm{~cm}$ in length, respectively (Fig. 1). The cores consisted of grayish black, fine-grained non-bioturbated sediments. Each core was sectioned into $2-\mathrm{cm}$ intervals in the field, and samples were packed in airtight zip-lock plastic bags and refrigerated. On freeze-drying, these samples yielded few grams of sediment $\left(\mathrm{g} \mathrm{dw}^{-1}\right)$ from each interval. Hence, radiometric dating and sulfur isotope analyses were performed on core BT 2, whereas other geochemical variables were measured on core BT 1 in order to have sufficient material for the assays. In both cores, 
loss-on-ignition (LOI) was measured (Heiri et al. 2001), and sample reproducibility of duplicate runs was about $\pm 3 \%$. Water content was determined in both cores by measuring the wet and dry sample weights.

Linear sedimentation rate $\left(\mathrm{mm} \mathrm{yr}^{-1}\right)$ was estimated by ${ }^{210} \mathrm{~Pb}$ activity (Appleby and Oldfield 1978). The ${ }^{210} \mathrm{~Pb}$ activity was obtained by measurement of ${ }^{210} \mathrm{Po}$, assuming secular equilibrium between the two radionuclides. The procedure involved adding ${ }^{209} \mathrm{Po}$ as a tracer and leaching the sediment with aqua regia. Polonium nuclides $\left({ }^{210} \mathrm{Po}\right.$ and ${ }^{209} \mathrm{Po}$ ) were deposited on copper discs prior to alpha counting. The standard counting error was $<10 \%$ in the upper section of the core, but increased slightly in deeper sections. The downcore asymptote value of total ${ }^{210} \mathrm{~Pb}$ activity was assumed to represent supported activity. Supported activity was subtracted from the total ${ }^{210} \mathrm{~Pb}$ activity to derive unsupported, i.e. excess ${ }^{210} \mathrm{~Pb}$ activity. Unsupported ${ }^{210} \mathrm{~Pb}$ activity was multiplied by dry density at corresponding depths to correct for sediment compaction. The constant initial concentration (CIC) dating model was applied and its slope represents the mean sedimentation rate.

The TOC and TN isotopic compositions of freeze-dried, acid-treated samples (Hedges and Stern 1984) were analyzed using a Carlo Erba elemental analyzer coupled to a Finnigan MAT Delta Plus mass spectrometer. Data were reported in conventional delta ( $\delta$ ) notation versus the Vienna PeeDee Belemnite standard (V-PDB) for C and versus atmospheric $\mathrm{N}_{2}$ for $\mathrm{N}$. Reproducibility of duplicate analyses was $\pm 0.1 \%$. The precision for isotope analysis with respect to the standards was $0.18 \%$ and $0.06 \%$ for $\mathrm{C}$ and $\mathrm{N}$, respectively. The $\mathrm{S}$ isotopes were measured in both the sulfate and sulfide fractions, and results were expressed in the conventional $\delta^{34} \mathrm{~S}$ notation relative to the Vienna-Canyon 
Diablo Troilite standard. Precision for $\mathrm{S}$ isotope analysis was $\pm 0.2 \%$ with respect to the standard.

For $n$-alkane analysis, approximately 1-2 g of freeze-dried sediment was extracted with a mixture of $\mathrm{CH}_{2} \mathrm{Cl}_{2}$ and $\mathrm{CH}_{3} \mathrm{OH}(9: 1 \mathrm{v} / \mathrm{v})$, using a Dionex Accelerated Solvent Extractor 300, programmed for three extraction cycles at $1000 \mathrm{psi}$ and $100^{\circ} \mathrm{C}$. The extracts were reduced using a Büchii rotovapor and injected in splitless mode into an Agilent 6890 gas chromatograph equipped with a HP5-MS column (30 m x 0.25 mm i.d. x $0.25 \mu \mathrm{m}$ film). The oven temperature was held at $35^{\circ} \mathrm{C}$ for $6 \mathrm{~min}$, increased to $300^{\circ} \mathrm{C}$ at $5^{\circ} \mathrm{C} \mathrm{min}^{-1}$ and held isothermal for 20 minutes. The chromatograph was interfaced with an Agilent 5973 mass spectrometer operated at $70 \mathrm{eV}$ in full-scan mode (mass/charge 50$500 \mathrm{amu}$ ); external and internal standards (S-4066 from CHIRON, Norway and deuterated perylene from Cambridge Laboratory, USA) were used for quantification.

The $n$-alkane concentrations were used to calculate various ratios for characterizing the sedimentary OM.

1) Carbon Preference Index (CPI; Allan and Douglas 1977):

$$
\mathrm{CPI}=\frac{\Sigma\left(\mathrm{C}_{23}-\mathrm{C}_{31}\right)_{\text {odd }}+\Sigma\left(\mathrm{C}_{25}-\mathrm{C}_{33}\right)_{\text {odd }}}{2 \Sigma\left(\mathrm{C}_{24}-\mathrm{C}_{32}\right)_{\text {even }}}
$$

2) Terrigenous Aquatic Ratio (TAR; Bourbonniere and Meyers 1996):

$$
\mathrm{TAR}=\frac{\left(\mathrm{C}_{15}+\mathrm{C}_{17}+\mathrm{C}_{19}\right)}{\left(\mathrm{C}_{27}+\mathrm{C}_{29}+\mathrm{C}_{31}\right)}
$$

Pigments were analyzed in two different ways after extracting them for 2 minutes by ultra-sonication in HPLC-grade acetone $\left(2 \mathrm{ml} \mathrm{g}^{-1}\right.$ sediment $)$, and filtering $(0.02 \mu \mathrm{m})$ the extracts. Rapid, simple colorimetric analysis (Dere et al. 1998) 
involved measuring absorbance in the sediment extracts at 470,645 , and $662 \mathrm{~nm}$ for chlorophyll and carotene. The concentrations of chlorophyll $a$ and $b$ (Chl $a$ and Chl b) and total carotenoids were estimated according to Lichtenthaler et al. (1985):

$$
\begin{aligned}
& \text { Chl } a=11.75 \mathrm{~A}_{662}-2.35 \mathrm{~A}_{645} \\
& \text { Chl } b=18.61 \mathrm{~A}_{645}-3.96 \mathrm{~A}_{662}
\end{aligned}
$$

$$
\text { Total carotene }=1000 \mathrm{~A}_{470}-2.270 \mathrm{Chl} a-81.4 \mathrm{Chl} b / 227
$$

Typical precision of duplicate runs for the colorimetric method was $\leq 4 \%$. The second method involved the HPLC technique which has better precision and reproducibility (Bianchi et al. 2002). Extracts were injected into a HPLC consisting of a Waters 2690 separation module coupled to a Waters 996 photodiode array UV/VIS detector, set at 450 $\mathrm{nm}$; the injector was connected via a guard column to a RP-18 LiChroCART column (5 $\mu \mathrm{m}$ particle size, $250 \mathrm{~mm} \times 4.6 \mathrm{~mm}$ i.d.). Typical precision of duplicate runs was $\leq 2.7 \%$.

\section{Results}

Sedimentation rate

Total ${ }^{210} \mathrm{~Pb}$ activity was plotted versus cumulative mass depth (Fig. 2). The curve showed a steady decline in activity from a maximum of $207 \mathrm{mBq} \mathrm{g}^{-1}$ in surface sediments to 56 $\mathrm{mBq} \mathrm{g}^{-1}$ at $21 \mathrm{~cm}$ depth. Below $21 \mathrm{~cm},{ }^{210} \mathrm{~Pb}$ activity was constant and assumed to represent supported activity. The mean linear sedimentation rate was calculated as 3.6 $\mathrm{mm} \mathrm{yr}^{-1}$, and based on this, the provisional age of the core was calculated as $\sim 102$ years 
(Fig. 2). The constant accumulation rate for the datable part of the core in Lake Bhimtal was $109 \mathrm{mg} \mathrm{cm}^{-2} \mathrm{yr}^{-1}$.

Elemental concentration and stable isotope trends

The TOC accumulation rate increased steadily up-core and values ranged between $9 \mathrm{~g} \mathrm{~m}^{-}$ ${ }^{2} \mathrm{yr}^{-1}$ and $35 \mathrm{~g} \mathrm{~m}^{-2} \mathrm{yr}^{-1}$; the minimum TOC accumulation rate occurred between 35 and 31 $\mathrm{cm}$ depth (Fig. 3). The total $\mathrm{N}$ accumulation rates were between $1.1 \mathrm{~g} \mathrm{~m}^{-2} \mathrm{yr}^{-1}$ and $4.1 \mathrm{~g}$ $\mathrm{m}^{-2} \mathrm{yr}^{-1}$, with the higher accumulation rates occurring in younger sediments $(5-1 \mathrm{~cm})$. The total $\mathrm{S}$ accumulation rates in the core were relatively high (up to $7.2 \mathrm{~g} \mathrm{~m}^{-2} \mathrm{yr}^{-1}$ ) at $15 \mathrm{~cm}$; minimum values were measured in bottom sediments $\left(2 \mathrm{~g} \mathrm{~m}^{-2} \mathrm{yr}^{-1}\right)$, whereas the upper half of the core indicated higher values $\left(4.4 \mathrm{~g} \mathrm{~m}^{-2} \mathrm{yr}^{-1}\right)$. The atomic $\mathrm{C} / \mathrm{N}$ ratio in sediments ranged between 8.6 and 11 . The $C / S_{\text {at }}$ ratio varied between 6.7 and 49 (Fig. 3).

The sulfate reduction index (SRI) was estimated to understand the diagenetic status of OM. This was calculated using the empirical relationship proposed by LallierVergès et al. (1993):

$$
\mathrm{SRI}=\frac{\% \text { Initial organic carbon }}{\% \text { Preserved organic carbon }}
$$

The initial organic carbon content was determined as the total preserved and oxidized $\mathrm{OM}$ in sediments. Organic matter degradation $\left(\mathrm{TOC}_{\mathrm{degr}}\right)$ via sulfate reduction was estimated by using the empirical relationship proposed by Vetõ et al. (1994):

$$
\mathrm{TOC}_{\mathrm{degr}}=\mathrm{S} * 0.75 * 1.33
$$


where $S$ is the total reduced $S$ in sediment; 0.75 is the factor derived used to convert reduced $\mathrm{S}$ into $\mathrm{OM}$ lost due to sulfate reduction based on atomic weights of $\mathrm{C}$ and $\mathrm{S}$ and stoichiometry in equation 8 . The value 1.33 corresponds to the assumed $25 \%$ diffusional loss of reduced $\mathrm{S}$ (mainly as $\mathrm{H}_{2} \mathrm{~S}$ ):

$$
2 \mathrm{CH}_{2} \mathrm{O}+\mathrm{SO}_{4}{ }^{2-} \rightarrow \mathrm{H}_{2} \mathrm{~S}+\mathrm{HCO}_{3}^{-}
$$

SRI in Bhimtal sediments varied between 0.94 and 1.3; the values were nearly constant ( 1.1) throughout the core (Fig. 4).

The $\delta^{13} \mathrm{C}$ values in $\mathrm{OM}$ ranged from $-24.6 \%$ to $-29.9 \%$; the lower values occurred in surface sediments (Fig. 5). The $\delta^{15} \mathrm{~N}$ values were almost constant (3.3\%o) until $11 \mathrm{~cm}$, after which the values decreased to $-0.2 \%$. The $\delta^{34} \mathrm{~S}$ values in sulfides fluctuated between $0.46 \%$ and $2.1 \%$. The $\delta^{34} \mathrm{~S}$ of sulfates increased steadily up-core, with the minimum value of $-0.65 \%$ measured at $37 \mathrm{~cm}$, after which the $\delta^{34} \mathrm{~S}$ values increased considerably, with the maximum value of 5.6\% at a depth of $7 \mathrm{~cm}$.

\section{Biomarker trends}

The $n$-alkane concentrations in sediments were normalized with respect to TOC in order to express the enrichment or depletion relative to bulk OC. Total $n$-alkane concentrations varied from 1.7 to $3.7 \mu \mathrm{g} \mathrm{mg}^{-1}$ of TOC, and showed an increase in concentration towards the top of the core (Fig. 6). The concentration of low odd numbered $n$-alkanes $\left(n-\mathrm{C}_{15}, \mathrm{C}_{17}\right.$ and $\left.\mathrm{C}_{19}\right)$ maintained nearly constant values $\left(0.55 \mu \mathrm{g} \mathrm{mg}^{-1}\right.$ of TOC) up to $11 \mathrm{~cm}$, after which, their concentrations increased in surface sediments and were between 0.64 and $0.91 \mu \mathrm{g} \mathrm{mg}^{-1}$ of TOC. CPI fluctuated between 1.6 and 4.9 and the average value was 3.7. 
The TAR values were low and varied between 0.14 and 2.4; TAR decreased above $11 \mathrm{~cm}$ and showed an erratic profile.

The total pigment concentration was between 2.7 and $16 \mathrm{mmol} \mathrm{g}^{-1}$ of TOC. Amongst the different pigments, zeaxanthin had higher concentrations and showed values between 1.0 and $6.7 \mathrm{mmol} \mathrm{g}^{-1}$ of TOC (Fig. 7). $\beta, \beta$-carotene was absent from the bottom of the core up to $25 \mathrm{~cm}$, but above this depth $\beta, \beta$-carotene was between 1.6 and 0.53 mmol $\mathrm{g}^{-1}$ of TOC. Echinenone was absent in the $35-33 \mathrm{~cm}$ and $19-13 \mathrm{~cm}$ intervals in the core, whereas high (5.7 to $7.4 \mathrm{mmol} \mathrm{g}^{-1}$ of TOC) concentrations occurred in surface sediments $(7-1 \mathrm{~cm})$. Lutein was abundant in the deeper sediments $(33-31 \mathrm{~cm})$ and ranged between 0.45 and $0.80 \mathrm{mmol} \mathrm{g}^{-1}$ of TOC, but was absent in surface sediments. Chl $a$ and $b$ concentrations varied from 0.05 to $1.3 \mathrm{mmol} \mathrm{g}^{-1}$ of TOC and 0.08 to $0.80 \mathrm{mmol} \mathrm{g}^{-1}$ of TOC, respectively. Chl a concentration was high $\left(1.3 \mathrm{mmol} \mathrm{g}^{-1}\right.$ of TOC) in surface sediments $(7-1 \mathrm{~cm})$, whereas $\mathrm{Chl} b$ indicated high values $\left(0.80 \mathrm{mmol} \mathrm{g}^{-1}\right.$ of TOC) at 29 cm depth. $\beta, \beta$-carotene was absent in bottom sediments $(35-25 \mathrm{~cm})$ and therefore, the ratios Chl $a / \beta, \beta$-carotene and zeaxanthin $/ \beta, \beta$-carotene were not plotted for depths below $25 \mathrm{~cm}$. These ratios however showed a steady up-core increase. Chl $a / \beta, \beta$-carotene increased to 2.6 towards the middle of the core, and zeaxanthin/ $\beta, \beta$-carotene reached 11 at $7 \mathrm{~cm}$ depth. The ratio of echinenone/zeaxanthin varied between 0.04 and 1.2.

\section{Paleoproductivity}

Paleoproductivity ( $P P ; \mathrm{g} \mathrm{C} \mathrm{m}^{-2} \mathrm{yr}^{-1}$ ) was calculated using the equation proposed by Müller and Suess (1979), which has been applied in different lake systems (Ishiwatari et 
al. 2005; Das et al. 2009; Routh et al. 2009), including the Kumaon lakes (Choudhary et al. 2009a, b):

$$
P P=(\% \mathrm{TOC} \times \mathrm{D}) /\left(0.0030 \times S^{0.3}\right)
$$

where D is dry bulk density $\left(\mathrm{g} \mathrm{cm}^{-3}\right)$ and $S$ is sedimentation rate $\left(\mathrm{cm} \mathrm{kyr}^{-1}\right)$. Paleoproductivity measured in these sediments varied significantly during the last century (Fig. 3). Higher $P P$ rates (540 to $750 \mathrm{~g} \mathrm{C} \mathrm{m}^{-2} \mathrm{yr}^{-1} ; 5-1 \mathrm{~cm}$ ) were measured in surface sediments, whereas relatively low (110 to $\left.260 \mathrm{~g} \mathrm{C} \mathrm{m}^{-2} \mathrm{yr}^{-1}\right) P P$ rates were observed in bottom sediments. Paleoproductivity was also estimated using the concentration of specific algal-derived $n$-alkanes ( $\sum n$ - $\mathrm{C}_{15,17,19}$ alkanes; Ishiwatari et al. 2005), which were converted into \% with respect to TOC before calculation. The highest value of algalderived $P P$ (14 to $\left.21 \mathrm{~g} \mathrm{C} \mathrm{m}^{-2} \mathrm{y}^{-1}\right)$ occurred in surface sediments $(7-1 \mathrm{~cm}) ; P P$ values

decreased (4 to $\left.11 \mathrm{~g} \mathrm{C} \mathrm{m}^{-2} \mathrm{yr}^{-1}\right)$ in deeper sediments $(35-27 \mathrm{~cm})$. Because these $n$-alkanes are diagnostic for algae and in situ primary productivity, they are probably more representative of changes within the lake rather than the TOC-based $P P$ assessment. Nonetheless, both variables indicate similar trends in $P P$ in the lake.

\section{Discussion}

Organic matter delivery has varied over the last 100+ years of depositional history preserved in the sediment cores retrieved from Lake Bhimtal. The observed changes are probably a consequence of anthropogenic activities that have markedly increased along with urban development in the catchment. We infer the changes in sedimentary OM characteristics in Lake Bhimtal using multiple geochemical variables that are further discussed below. 
Sediment chronology

The Bhimtal cores (BT 1 and BT 2) were retrieved within $1 \mathrm{~m}$ of one another during sampling in 2004, and they possess similar color, texture, and porosity (data not shown). LOI measurements in these non-bioturbated cores are comparable (Fig. 3). Moreover, the sediments are fine-grained and the cores do not show abrupt changes in lithology, which would affect accumulation or sorption of radiogenic isotopes. Therefore, extrapolating the ages from core BT 2 to BT 1, in which most of the geochemical variables were measured, while not ideal, is considered acceptable.

We applied the CIC model to the ${ }^{210} \mathrm{~Pb}$ data to calculate ages because: 1) ${ }^{210} \mathrm{~Pb}$ activity displays a semi-logarithmic trend characterized by a monotonic decline until a depth at which unchanging ${ }^{210} \mathrm{~Pb}$ concentration is reached, and 2) the plot of natural logarithm of excess ${ }^{210} \mathrm{~Pb}$ vs. cumulative mass is linear (Fig. 2). However, absence of alternative data for establishing the age/depth relations, e.g. ${ }^{137} \mathrm{Cs}$ or ${ }^{239,240,241} \mathrm{Pu}$, and the young age estimated at the supported-unsupported ${ }^{210} \mathrm{~Pb}$ boundary, raise questions about the chronology. Appleby (2001) indicated that low ${ }^{210} \mathrm{~Pb}$ activity can result from poor retention of atmospheric ${ }^{210} \mathrm{~Pb}$ as a consequence of local environmental conditions. Moreover, if surface sediments display low ${ }^{210} \mathrm{~Pb}$ activity, values may be very low and hard to measure after only two half-lives (44.6 years), making it difficult to determine the age of older deposits. This phenomenon has been reported in other sediment archives too. For example, LeRoux and Marshall (2011) indicated that low surface activity in peats resulted in young ages at the supported-unsupported ${ }^{210} \mathrm{~Pb}$ boundary. In sediments with 
low organic matter content, ${ }^{210} \mathrm{~Pb}$ activity in surface sediments may be low because of dilution by rapidly accumulating inorganic matter (Appleby 2001).

The CIC model was applied in previous studies to estimate sediment ages in Lake Bhimtal (Das et al. 1994; Kumar et al. 2007). Das et al. (1994) reported a sedimentation rate of $4.7 \mathrm{~mm} \mathrm{yr}^{-1}$, which is somewhat higher than the present study. The exact location of the core was not indicated, and sampling resolution in the core was low. Kumar et al. (2007) reported that sedimentation rate in Lake Bhimtal varied from $3.8 \pm 0.3$ to $9.5 \pm 0.4$ $\mathrm{mm} \mathrm{yr}^{-1}$. The authors reported higher sedimentation rate near the fringes of the lake due to frequent landslides. In contrast, deeper parts of the lake experience lower sedimentation rates, and their results are similar to our study. Moreover, historical changes associated with rapid urbanization in the catchment coincide with the CICderived ages for changes in the core (see below). Despite this evidence, we consider the age-depth relations to be provisional and refer to ages as 'model dates'.

Organic matter sources

The multiple geochemical variables investigated in this study indicate the different OM sources in Lake Bhimtal. The $\mathrm{C} / \mathrm{N}_{\mathrm{at}}$ ratio between 9.4 and 11 indicates a dominant algal component in these sediments. Algal-derived OM generally shows $\delta^{13} \mathrm{C}$ values between $20 \%$ and $-30 \%$, whereas $\mathrm{C}_{3}$ vascular plants have values between $-25 \%$ and $-30 \%$ (Meyers 2003). Therefore, bulk $\delta^{13} \mathrm{C}$ values of sediment $\mathrm{OM}$ are mostly unreliable as source indicators in lacustrine systems (Meyers 1997, 2003). Together with other geochemical variables, however, the $\delta^{13} \mathrm{C}$ values can be useful in tracking $\mathrm{OM}$ sources 
and ongoing biogeochemical processes in lakes (Routh et al. 2004, 2009; Choudhary et al. 2009a). In contrast, $\delta^{15} \mathrm{~N}$ values tend to be diagnostic because OM produced by phytoplankton and terrestrial plants has significantly different isotopic signatures. The $\delta^{15} \mathrm{~N}$ values in phytoplankton range between $7 \%$ and $10 \%$, whereas land plants and cyanobacteria show values between 0\%o and 2\%o (Meyers 1997, 2003). Thus, elemental accumulation rates, $\delta^{13} \mathrm{C}\left(-24.6 \%\right.$ o to $-29.9 \%$ ) and $\delta^{15} \mathrm{~N}(-0.2 \%$ o to $3.3 \%$ ) values in these sediments indicate an algal-dominated OM source, which has not changed over the last 100+ years in Lake Bhimtal.

The abundance of short-chain $n$-alkanes $\left(\sum n-\mathrm{C}_{15,17,19}\right)$ indicates dominance of an algal-derived contribution to the lacustrine OM pool in these sediments (Cranwell et al. 1987; Rieley et al. 1991). Likewise, TAR, which is a measure of the ratio between terrestrial and aquatic inputs of $\mathrm{OM}$, is low (0.3 and 2.4), implying the dominance of algal-derived OM in Bhimtal sediments. These sediments also indicate low (1.6-5.0) CPI values, which are indicative of OM derived from aquatic sources (Rieley et al. 1991). Presence of algal-derived compounds in these sediments is also evident based on the presence of diagnostic pigments such as echinenone and zeaxanthin (cyanobacteria) and lutein (chlorophytes).

Lacustrine productivity

Organic matter preserved in Lake Bhimtal sediments records changes in the watershed, and their impact on the lake, e.g. primary productivity and trophic state shifts associated with anthropogenic activities. The TOC accumulation rates quadrupled from $9 \mathrm{~g} \mathrm{~m}^{-2} \mathrm{yr}^{-1}$ in bottom sediments $(35-30 \mathrm{~cm})$ to $35 \mathrm{~g} \mathrm{~m}^{-2} \mathrm{yr}^{-1}$ in surface sediments $(3-1 \mathrm{~cm}$; Fig. 3). 
The low TOC, total $\mathrm{N}$, and $P P$ values based on TOC in bottom sediments $(35-30 \mathrm{~cm})$ suggest that Lake Bhimtal was oligotrophic to mesotrophic during the early $20^{\text {th }}$ century, before the lake became eutrophic. Consistent with this, the $\sum n-\mathrm{C}_{15,17,19}$ alkane concentrations during AD 1900-1950 (35-25 cm) are low (0.60-0.62 $\mu \mathrm{g} \mathrm{mg}^{-1}$ of TOC), and signify low $P P$ and input of algal-derived OM. After the 1950s $(25-20 \mathrm{~cm})$, TOC, total N, and $P P$ profiles co-vary and show a steady increase in the core. These geochemical trends reflect an increase in external input of nutrients, which increase primary productivity. Consistent with this, lipid extracts dominated by $n$ - $\mathrm{C}_{15,17,19}$ alkanes show an up-core increase and mirror the TOC and PP profiles (Figs. 3 and 6). The external input of nutrients increases during the 1960s, and coincides with discharge of sewage and rapid urbanization in the catchment (Chakrapani 2000; Das 2005).

Under eutrophic conditions, elevated productivity leaves $\mathrm{OM}$ enriched in ${ }^{13} \mathrm{C}$ (Schelske and Hodell 1995; Brenner et al. 1999; Routh et al. 2009). Hence, the steady upcore decrease in $\delta^{13} \mathrm{C}$ values, despite the elevated productivity and eutrophic conditions in the younger sediments (above $25 \mathrm{~cm}$ ), is surprising. Teranes and Bernasconi (2000) indicated that under eutrophic conditions, OM produced by methanotrophic bacteria results in ${ }^{13} \mathrm{C}$-depleted values. Presence of these bacteria and methanogenesis in Lake Bhimtal sediments is, however, unknown. Contribution of isotopically depleted $\mathrm{CO}_{2}$ as a result of fossil fuel burning and sewage input could perhaps result in the low $\delta^{13} \mathrm{C}$ values (Schelske and Hodell 1995; Meyers and Teranes 2001). It is likely multiple processes influence the $\delta^{13} \mathrm{C}$ values in Lake Bhimtal, and the data are insufficient to identify the specific processes that determine such values. 
The $\delta^{15} \mathrm{~N}$ values in Bhimtal sediments display a gradual up-core decline from $3.9 \%$ to $-0.2 \%$ near surface (Fig. 5). The low $\delta^{15} \mathrm{~N}$ values in these sediments suggest the presence of cyanobacteria, which tend to produce $\mathrm{OM}$ depleted in ${ }^{15} \mathrm{~N}$ (Brenner et al. 1999; Routh et al. 2004, 2009; Das et al. 2009). Typically, OM produced by cyanobacteria in eutrophic lakes has $\delta^{15} \mathrm{~N}$ values of $-3 \%$ to $1 \%$, especially under conditions of high P-flux and N-limited conditions (Brenner et al. 1999; Talbot 2001). In support, a recent study by Das (2005) indicated increases in P levels to $6.7 \mu \mathrm{g}^{-1}$ in Lake Bhimtal. It is likely the non- $\mathrm{N}_{2}$-fixing phytoplankton $\left(\delta^{15} \mathrm{~N}>2 \%\right.$; Talbot 2001$)$ also play a significant role, particularly in the deeper sediments $(35-19 \mathrm{~cm})$, where ${ }^{15} \mathrm{~N}$ is enriched. Evidently, the lake had a mixed phytoplankton community in the water column, which gradually changed to a system dominated by cyanobacteria as nutrient input increased after the 1960s (see below). The same trend is observed in other Kumaon lakes (Choudhary et al. 2009a, b), indicating the impact of human-induced processes on phytoplankton in these remote mountain lakes.

Phytoplankton diversity

Total pigment concentrations in Lake Bhimtal sediments show an increase in surface sediments (7-1 cm, Fig. 7). This trend mirrors the distribution of TOC, N, and PP shifts (Fig. 3), and is related to enhanced productivity in the lake as a consequence of humaninduced changes in the catchment. Chl $a$ and $\mathrm{Chl} b$ occur throughout the core and show similar profiles (Fig. 7). The low concentrations of Chl $a$ and Chl $b\left(0.15 \mu\right.$ mol g $\mathrm{g}^{-1}$ of TOC and $0.01 \mu \mathrm{mol} \mathrm{g}^{-1}$ of TOC, respectively) before AD $1930(29 \mathrm{~cm})$ are related to low 
productivity, which is consistent with the $P P$ and stable isotope interpretation. The concentration of Chl $a$ steadily increases in younger sediments $(13-1 \mathrm{~cm})$, and it implies increased productivity in recent years. In contrast, Chl $b$ concentration shows greatest values around $30-29 \mathrm{~cm}$. These pigments, however, are susceptible to diagenetic alteration (Leavitt 1993), and hence their low concentration in earlier years may be related to the low stability of these compounds. Lutein, a marker for chlorophytes (Leavitt et al. 1989; Leavitt and Hodgson 2001), is abundant during the 1930s, implying abundance of green algae in the water column. Lutein, however, practically disappears after AD 1961 (21-1 cm), except for a small resurgence around AD 1990. Because lutein is a relatively stable compound compared to other pigments (Leavitt 1993; Bianchi et al. 2000), variation in its distribution signifies a distinct change in phytoplankton diversity in Lake Bhimtal.

Amongst the different carotenoids analyzed in Bhimtal sediments, the cyanobacteria-specific pigments, i.e. echinenone and zeaxanthin, indicate higher concentrations than lutein and $\beta, \beta$-carotene. The ratio between zeaxanthin and $\beta, \beta$ carotene represents a linear increase; this trend suggests an increase in cyanobacteria (Bianchi et al. 2000; Borgendahl and Westman 2003; Choudhary et al. 2009a,b) that started around AD $1960(21 \mathrm{~cm})$. Likewise, the high concentration and steady up-core increase of zeaxanthin and echinenone suggest a $\mathrm{N}_{2}$-limited environment, which favored cyanobacterial dominance over other species (Leavitt 1993; Bianchi et al. 2000). The low concentration or near absence of echinenone in bottom sediments $(37-29 \mathrm{~cm})$ could be related to degradation because echinenone is unstable and degrades faster than zeaxanthin (Leavitt 1993; Bianchi et al. 2000). 
$\beta, \beta$-carotene, an indicator for algae and higher plants is absent in the bottom sediments $(37-29 \mathrm{~cm})$, but its concentration increases substantially from $25 \mathrm{~cm}$ and above. $\beta, \beta$-carotene is a stable pigment, and its absence in bottom sediments is probably unrelated to degradation processes (Bianchi et al. 2000; Leavitt and Hodgson 2001), but is instead related to low productivity during the early $20^{\text {th }}$ century, as implied by other geochemical variables. Because input from terrestrial OM sources is low, as indicated by $\mathrm{C} / \mathrm{N}, n$-alkanes, and stable isotope evidence, the sharp increase in $\beta, \beta$-carotene concentration after AD $1950(25-1 \mathrm{~cm})$ is related to enhanced primary productivity and growth of green algae in the water column.

Organic matter degradation

Once organic-rich sediments are deposited, $\mathrm{C} / \mathrm{N}$ values experience very little change (Meyers and Teranes 2001), and any variation in this ratio reflects a change in OM input rather than a diagenetic artifact (Kaushal and Binford 1999; Meyers 2003). Exceptions to this norm, however, have been reported in recent studies (Lehmann et al. 2002; Gälman et al. 2008). These studies conclude that most $\mathrm{C}$ and $\mathrm{N}$ loss occurs during the early stages of deposition, and thereafter, the loss is low. Below, we discuss OM degradation in Bhimtal sediments using elemental ratios, stable $\mathrm{C}$ isotopes, and biomarker trends.

The total S accumulation rate in Bhimtal sediments before AD $1960(38-21 \mathrm{~cm})$ is low (Fig. 3). Sulfur accumulation increases after $21 \mathrm{~cm}$ and reaches a maximum at $17 \mathrm{~cm}$, before there is a decline. It has been reported that bacterial sulfate reduction in eutrophic lakes can contribute to high $\mathrm{S}$ levels from anthropogenic activities (Putschew et al. 
1995; Urban et al. 1999). Hence, the elevated accumulation rate of $S$ in recent years is probably related to anthropogenic activities. A similar trend occurs in Lake Nainital and the increase in S accumulation correlates with anthropogenic input from the catchment (Choudhary et al. 2009a).

The C/S ratio is low (0.4-8.5) in the sediment intervals from $37-31 \mathrm{~cm}$ and $19-10$ $\mathrm{cm}$, which implies these sediments are reducing in nature. The low $\mathrm{C} / \mathrm{S}$ ratio is likely related to greater sulfate reduction and accumulation of sulfide minerals. This is consistent with the SRI values, which describes the ratio between labile and refractory carbon in sediments (Lallier-Vergès et al. 1993). High SRI values, in conjunction with low TOC accumulation rates, suggest greater availability of labile OM, whereas low SRIs with high TOC values are typical of recalcitrant OM. In Lake Bhimtal, sediments belonging to group $X$ (sediment intervals extending from $37-31 \mathrm{~cm}$ and $19-10 \mathrm{~cm}$; Fig. 4) indicate high SRI (1.3), but low TOC (0.8-1.5\%) values, implying the presence of labile OM. These sediment intervals have low $\delta^{34} \mathrm{~S}$ values in the sulfate and sulfide fractions (Fig. 5). The $\delta^{34} \mathrm{~S}$ values can be interpreted in terms of microbial degradation and availability of labile OM (Choudhary et al. 2009a). Supply of labile OM supports microbial sulfate reduction, and in the process, the whole sulfate fraction in this interval is probably consumed. Complete consumption of the sulfate pool results in less isotopic fractionation (Grossman and Desrocher 2001; Choudhary et al. 2009a) and hence, $\delta^{34} \mathrm{~S}$ values appear to be similar in both the oxidized and reduced $\mathrm{S}$ fractions. Similarly, $\delta^{13} \mathrm{C}$ enrichment of $\mathrm{OM}$ in these sediments indicates preferential loss of ${ }^{12} \mathrm{C}$ during microbial degradation of OM (Schelske and Hodell 1995; Brenner et al. 1999). Consistent with this, 
samples from the sediment interval lying between 37 and $31 \mathrm{~cm}$ show a positive shift in $\delta^{13} \mathrm{C}$ values, and suggest enhanced degradation of OM.

The C/S profile indicates two distinct peaks: a) $27-21 \mathrm{~cm}$, with $\mathrm{C} / \mathrm{S}$ ratio increasing from 28 to 49 , and b) 10-1 cm, with C/S ratio increasing from 15 to 35 (Fig. 4). The high C/S ratio in these sediments is unusual for freshwater systems (Berner and Roswell 1984), and results from the low accumulation of $\mathrm{S}$ compared to $\mathrm{C}$. This condition develops when the availability of reactive OM decreases, resulting in selective preservation in sedimentary environments (Lallier-Vergès et al. 1997). Hence, samples in group Y (Fig. 4) belonging to the sediment intervals $27-21 \mathrm{~cm}$ and $11-1 \mathrm{~cm}$ indicate SRI (1.0-1.2) with higher (1.7-3.3\%) TOC values; the results suggest more recalcitrant OM in these intervals (Lallier-Vergès et al. 1997). This is consistent with the $\delta^{34} \mathrm{~S}$ values, which show greater variation, particularly in the upper $10 \mathrm{~cm}$ of the core. During normal rates of bacterial sulfate reduction, the $\delta^{34} \mathrm{~S}$ of dissolved sulfate becomes high and exceeds the $\delta^{34} \mathrm{~S}$ of sulfide (Grossman and Desrocher 2001). Hence, less rapid OM consumption allows larger isotopic fractionation in sediments.

Comparison with other lakes in the Kumaon region

The systematic application of different physical and geochemical variables in ongoing studies on the Kumaon mountain lakes (Chakrapani 2002; Das 2005; Choudhary et al. 2009a, b; 2010) demonstrates their use in exploring the historical and environmental changes in these water bodies. Direct response to climate change is less perceptible, at least using the set of variables measured in this study. It is evident, however, that these 
mountain lakes have consistently and uniformly responded to anthropogenic activities in their catchments, resulting in deterioration of water and sediment quality. These changes are fairly well preserved in the sediment record, and highlight the utility of geochemical variables for reconstructing the paleoenvironment and trophic state in lake systems, in the absence of long-term water quality data. The Kumaon mountain lake studies indicate that:

1) the vulnerability of these water bodies to external input of nutrients,

2) the closer the lakes are to the city limits, the higher is the environmental impact and stress on these lakes, following an approximate trend: Nainital > Bhimtal > Sattal $\geq$ Naukuchiatal,

3) in-lake algal-derived OM is the primary source of organic carbon in these sediments. Input of terrestrial OM into these lakes, e.g. vascular plant matter brought by erosional processes or groundwater discharge, is limited,

4) diagenetic changes associated with microbial degradation have altered the distribution of TOC and stable isotopes and to some extent biomarkers, but these changes can be discerned,

5) increases in anthropogenic activities since the 1960s coincide with rapid urbanization. This change had a negative impact on the Kumaon lakes,

6) input of nutrients has steadily increased primary productivity in the water column. This modified the trophic state, which changed from oligotrophic/mesotrophic to eutrophic. This change in trophic state is preserved in OM deposited in the lake sediments, and 
7) there has been an increase in cyanobacteria in all these lakes since the 1960s and they became the dominant species in the water column.

Direct impact of external nutrient inputs $\mathrm{P}$ and $\mathrm{N}$, which changed primary productivity and trophic state in these mountain lakes, is most evident in Lakes Bhimtal and Sattal (Choudhary et al. 2009b). Both lakes are remote and the impacts of anthropogenic activities are distinct and recognizable. In particular, the phytoplankton community shift in these lakes, as a response to external input of nutrients, and its longterm effect on lacustrine ecology, is an important concern. Although productivity increased over the last three decades in Lake Nainital, the lake was already eutrophic at the start of the $20^{\text {th }}$ century (Choudhary et al. 2009a), the time span of our paleolimnological investigation. Consequences of long-term anoxia and toxic pollutants are evident in Lake Nainital, where several fish kills have been reported (Ali et al. 1999; Singh et al. 2001; Nagdali and Gupta 2002). Whereas several remediation actions are in place to improve water quality in Lake Nainital, such measures need to be implemented in other anthropogenically impacted lakes in the Kumaon region.

\section{Conclusions}

Geochemical variables in Lake Bhimtal sediments indicate an increase in primary productivity and as a result of a change in its trophic state, which correlates temporally with an increase in anthropogenic activities. Accumulation rates of $\mathrm{C}$ and $\mathrm{N}$, and $P P$, increase steadily up-core. $\mathrm{C} / \mathrm{N}$ ratios and dominance of $\sum n-\mathrm{C}_{15,17,19}$ alkanes represent $\mathrm{OM}$ derived from algal sources, which is associated with enhanced primary productivity. 
Occurrence of zeaxanthin and echinenone indicate the presence of cyanobacteria, which gradually became the dominant species in the water column after the 1960s, signifying a change in the lake's trophic state. The $\delta^{13} \mathrm{C}$ values are relatively low in surface sediments and these changes may be due to in-lake processes or external inputs from the lake's

catchment. The up-core decrease in $\delta^{15} \mathrm{~N}$ values signifies an increase in $\mathrm{N}_{2}$-fixation by cyanobacteria, which is typical of productive lakes. The $\mathrm{C} / \mathrm{S}$ ratio and $\mathrm{S}$ isotope data represent OM degradation, and SRI indicates the role of OM lability and microbial processes. Finally, it is evident from this study that in the absence of instrumental records, multiple geochemical variables can be applied to sediment cores from lake systems that have undergone changes in OM input and anthropogenic activities in the catchment, to reconstruct their paleoenvironmental history.

\section{Acknowledgements}

P. Parthasarathy and R. Saini helped in sampling the lake. Supriyo Das assisted with pigment analysis. Dr. Bhishm Kumar is acknowledged for providing the lab facilities for lead dating. Discussions with Val Klump and Mark Baskaran on sediment chronology were helpful. Andrea Baker reviewed an earlier draft of the manuscript. Suggestions by editor Mark Brenner and two anonymous reviewers greatly improved the manuscript. We thank the Swedish Research Link-Asia program and CSIR (India) for supporting the study. 


\section{References}

Ali MB, Tripathi RD, Rai UN, Pal A, Singh SP (1999) Physico-chemical characteristic and pollution level of lake Nainital (UP, India): role of macrophytes and phytoplankton in biomonitoring and phytoremediation of toxic metal ions. Chemosphere 39:2171-2182.

Appleby PG (2001) Chronostratigraphic techniques in recent sediments. In: Last WM, Smol JP (eds) Tracking Environmental Change Using Lake Sediments. Basin Analysis, Coring, and Chronological Techniques. Volume 1. Kluwer Academic Publishers, Dordrecht, pp 171-203

Appleby PG, Oldfield F (1978) The calculation of ${ }^{210} \mathrm{~Pb}$ dates assuming a constant rate of supply of unsupported ${ }^{210} \mathrm{~Pb}$ to the sediments. Catena $5: 1-8$

Allan J, Douglas AG (1977) Variations in the content and distribution of n-alkanes in a series of Carboniferous vitrinites and sporinites of bituminous rank. Geochim Cosmochim Acta 41:1223-1230

Battarbee RW, Grytnes JA, Thompson R, Appleby PG, Catalan J, Korhola A, Birks HIB, Heegard E, Lami A (2002) Comparing palaeolimnological and instrumental evidence of climatic change for remote mountain lakes over last 200 years. J Paleolimnol 28: $161-179$

Berner RA, Raiswell R (1984) C/S method for distinguishing freshwater from marine sedimentary rocks. Geology 12:365-368 
Bianchi TS, Rolff C, Widbom B, Elmgren R (2002) Phytoplankton pigments in Baltic Sea sestoon and sediments: seasonal variability, fluxes and transformations. Estuar Coastal Shelf Sci 55:369-383

Bianchi TS, Westman P, Rolff C, Engelhaupt E, Andrén T, Elmgren R (2000) Cyanobacterial blooms in Baltic Sea: natural or human induced? Limnol Oceanogr $45: 716-726$

Borgendahl J, Westman P (2007) Cyanobacteria as a trigger fro increase primary productivity during sapropel formation in the Baltic Sea - a study of the Ancylus/Litorina transition. J Paleolimnol 38:1-12

Bourbonniere RA, Meyers PA (1996) Sedimentary geolipid records of historical changes in the watersheds and productivities of Lake Ontario and Erie. Limnol Oceanogr $41: 352-359$

Brenner M, Whitmore TJ, Curtis JH, Hodell DA, Schelske CL (1999) Stable isotope $\left(\delta^{13} \mathrm{C}\right.$ and $\left.\delta^{15} \mathrm{~N}\right)$ signatures of sedimented organic matter as indicators of historic lake trophic state. J Paleolimnol 22:205-221

Chakrapani GJ (2002) Water and sediment geochemistry of major Kumaun Himalayan lakes, India. Environ Geol 43:99-107

Choudhary P, Routh J (2010) Distribution of polycyclic aromatic hydrocarbons in Kumaun Himalayan Lakes, northwest India. Org Geochem 41:891-894

Choudhary P, Routh J, Chakrapani GJ, Kumar B (2009a) Organic matter and stable isotopic record of paleoenvironmental changes in sediments from Nainital Lake in Kumaun Himalayas, India. J Paleolimnol 42:571-586 
Choudhary P, Routh J, Chakrapani GJ (2009b) An environmental record of changes in sedimentary organic matter from Lake Sattal in Kumaun Himalayas, India. Sci Total Environ 407:2783-2795

Cranwell PA, Eglinton G, Robinson N (1987) Lipids of aquatic organisms as potential contribution to lacustrine sediments - II. Org Geochem11:513-527

Das S, Routh J, Roychoudhury AN (2009) Biomarker evidence of macrophytes and phytoplankton community change in a shallow lake, Zeekoevlei, South Africa. J Paleolimnol 41:507-521

Das BK (2005) Environmental pollution impact on water and sediments of Kumaun lakes, lesser Himalaya, India: a comparative study. Environ Geol 49:230-239

Das BK, Singh M, Borkar MD (1994) Sediments accumulation rate in the lakes of Kumaun Himalaya, India using ${ }^{210} \mathrm{~Pb}$ and ${ }^{226} \mathrm{Ra}$. Environ Geol 23:114-118

Dere S, Güneş T, Sivaci R (1998) Spectrophotometric determination of chlorophyll - a, b and total carotenoid contents of some algae species using different solvents. Tr J Bot 22:13-17

Gälman V, Rydberg J, de-Luna SS, Bindler R, Renberg I (2008) Carbon and nitrogen loss rates during aging of lake sediment: changes over 27 years studied in varved lake sediment. Limnol Oceanogr 53:1076-1082

Grossman EL, Desrocher S (2001) Microbial sulfur cycling in terrestrial subsurface environments. In: Fredrickson JK, Fletcher M (eds) Subsurface Microbiology and Biogeochemistry, Wiley-Liss Inc, pp. 219-248

Hedges JI, Stern JH (1984) Carbon and Nitrogen determination of carbonate-containing solids. Limnol Oceanogr 29:663-666 
Heiri O, Lotter AF, Lemcke G (2001) Loss on ignition as a method for estimating organic and carbonate content in sediments: reproducibility and comparability of results. $\mathbf{J}$ Paleolimnol 25:101-110

Hodell DA, Schelske CL (1998) Production, sedimentation and isotopic composition of organic matter in Lake Ontario. Limnol Oceanogr 43:200-214

Ishiwatari R, Yamamoto S, Uemura H (2005) Lipid and lignin/cutin compounds in Lake Baikal sediments over the last 37 kyr: implications for glacial-interglacial palaeoenvironmental change. Org Geochem 36:327-347

Kaushal S, Binford MW (1999) Relationship between C:N ratios of lake sediments, organic matter sources, and historical deforestation of Lake Pleasant, Massachusetts, USA. J Paleolimnol 22:432-442

Kumar B, Rai SP, Nachiappan RP, Kumar SU, Singh S, Diwedi VK (2007) Sedimentation rate in North Indian lakes estimated using ${ }^{137} \mathrm{Cs}$ and ${ }^{210} \mathrm{~Pb}$ dating techniques. Curr Sci 92:10-25

Lallier-Vergès E, Hayes JM, Boussafir M, Zaback DA, Tribovillard NP, Connan J, Bertrand P (1997) Productivity-induced sulphur enrichment of hydrocarbon-rich sediments from the Kimmeridge Clay Formation. Chem Geol 134:277-288

Lallier-Vergès E, Bertrand P, Desprairies A (1993) Organic matter composition and sulphate reduction intensity in Oman margin sediments. Mar Geol 112:57-69

Leavitt PR, Hodgson DA (2001) Sedimentary pigments. In: Smol JP, Birks HJB, Last WM (Eds) Tracking Environmental Change Using Lake Sediments. Vol 3: Terrestrial, Algal and Siliceous Indicators. Kluwer Academic Publishers, Dodrecht, The Netherlands, pp. 255-262 
Leavitt PR (1993) A review of factors that regulate carotenoid and chlorophyll deposition and fossil abundance. J Paleolimnol 9:109-127

Leavitt PR, Carpenter SR, Kitchell JF (1989) Whole-lake experiments: the annual record of fossil pigments and zooplankton. Limnol Oceanogr 34:700-717

Lehmann MF, Bernasconi SM, Barbieri A, McKenzie JA (2002) Preservation of organic matter and alteration of its carbon and nitrogen isotope composition during simulated and in situ early sedimentary diagenesis. Geochim Cosmochim Acta 66:3573-3584

Lichtenthaler HK, Wellburn AR (1985) Determination of total carotenoids and chlorophylls a and b of leaf in different solvents. Biol Soc Transac 11:591-592

Meyers PA (2003) Applications of organic geochemistry of paleolimnological reconstructions: a summary of examples from the Laurentian Great Lakes. Org Geochem 34:261-289

Meyers PA, Teranes JL (2001) Sediment organic matter. In: Last WM, Smol JP (Eds) Tracking Environmental Change Using Lake Sediments, Physical and Geochemical Methods. Vol 2. Kluwer Academic Publishers, Dordrecht, pp 239-269

Meyers PA (1997) Organic geochemical proxies of paleoceanographic, paleolimnologic, and palaeoclimatic processes. Org Geochem 27:213-250

Müller PJ, Suess E (1979) Productivity, sedimentation rate, and sedimentary organic matter in the oceans - I. Organic carbon preservation. Deep-Sea Res 26A:1347-1362

Nagdali SS, Gupta PK (2002) Impact of mass mortality of a mosquito fish, Gambusiaaffinis on the ecology of fresh water eutropic lake (Lake Nainital, India). Hydrobiologia 468:45-52 
Putschew A, Scholz-Böttcher BM, Rullkötter J (1995) Organic geochemistry of sulfurrich surface sediments of meromictic Lake Cadango, Swiss Alps. In: Vairavamurthy MA, Schoonen MAA (eds) Geochemical transformations of sedimentary sulfur. ACS Symposium Series 612, pp 59-79

Rieley G, Collier, RJ, Jones DM, Eglinton G (1991) The biogeochemistry of Ellesmere Lake, U.K. I: source correlation of leaf wax inputs to the sedimentary record. Org Geochem 17:901-912

Routh J, Meyers PA, Gustafsson Ö, Baskaran M, Hallberg R, Scholdström A (2004) Sedimentary geochemical record of human induced environmental changes in the Lake Brunnsviken watershed, Sweden. Limnol Oceanogr 49:1560-1569

Routh J, Choudhary P, Meyers PA, Kumar B (2009) Sedimentary record of nutrient loadings and recent trophic changes in Lake Norrviken, Sweden. J Paleolimnol 42: $325-341$

Roux L, Marshall WA (2010) Constructing recent peat accumulation chronologies using atmospheric fall-out radionuclides. Mires and Peat 7:1-14

Schelske CL, Hodell DA (1995) Using carbon isotopes of bulk sedimentary organic matter to reconstruct the history of nutrient loading and eutrophication in Lake Erie. Limnol Oceanogr 40:918-929

Sharma AP, Jaiswal S, Negi V, Pant MC (1982) Phytoplankton community analysis in lakes of Kumaon Himalaya. Arch Hydrobiol 93:173-193

Singh SP, Gopal B, Kathuria V (2001) Integrated management of water resources of Lake Nainital and its watershed: An environmental economics approach. EERC Report, Indira Gandhi Institute for Developmental Research, Mumbai. 39 pp. 
Talbot MR (2001) Nitrogen isotopes in paleolimnology. In: Last WM, Smol JP (eds) Tracking Environmental Changes Using Lake Sediments. Physical and Geochemical Methods.Volume 2. Kluwer Academic Publishers, Dordrecht, pp 401-439

Teranes JL, Bernasconi SM (2000) The record of nitrate utilization and productivity limitation provided by $\delta^{15} \mathrm{~N}$ values in lake organic matter - a study of sediment trap and core sediments from Baldeggersee Switzerland. Limnol Oceanogr 45: 801-813

Urban NR, Ernst K, Bernasconi S (1999) Addition of sulfur to organic matter during early diagenesis of lake sediments. Geochim Cosmochim Acta 63:837-853

Valdiya KS (1988) Geology and Natural Environment of Nainital Hills, Kumaun Himalaya. Gyanodaya Prakashan, Nainital, India. pp 1-156

Vetõ I, Hetényi M, Demény A, Hertelendi E (1994) Hydrogen index as reflecting intensity of sulphidic diagenesis in non-bioturbated, shaly sediments. Org Geochem 22:299-310

Vreča P, Muri G (2006) Changes in accumulation of organic matter and stable carbon and nitrogen isotopes in sediments of two Slovenian mountain lakes (Lake Ledvica and Lake Planina) induced by eutrophication changes. Limnol Oceanogr 51:781-790 


\section{FIGURE CAPTIONS}

Fig. 1 Bathymetric map of Lake Bhimtal showing the sampling location (modified from Nainital Development Authority 2002). The cores (BT1 and BT2) were retrieved within 1 $\mathrm{m}$ of each other

Fig. 2 Distribution of ${ }^{210} \mathrm{~Pb}$ and mass accumulation rate in Lake Bhimtal (core BT 2). Dates were calculated using the CIC model and represent provisional ages

Fig. 3 LOI, total organic carbon (TOC), total nitrogen, total sulfur, sulfate and sulfide, $\mathrm{C} / \mathrm{N}$ (atomic), $\mathrm{C} / \mathrm{S}$ (atomic), and paleoproductivity in Lake Bhimtal sediments

Fig. 4 Correlation between sulfate reduction index (SRI) and TOC in Lake Bhimtal. Group X (sediment intervals from 37-31 cm and 19-10 cm) and Group Y (sediment intervals from $27-21 \mathrm{~cm}$ and $11-1 \mathrm{~cm}$ )

Fig. $5 \delta^{13} \mathrm{C}_{\text {organic }}, \delta^{15} \mathrm{~N}_{\text {total }}, \delta^{34} \mathrm{~S}$ sulfide and $\delta^{34} \mathrm{~S}$ sulfate versus depth in Lake Bhimtal sediments ( $\mathrm{S}$ isotopes were analyzed in core BT 1, whereas $\mathrm{C}$ and $\mathrm{N}$ isotopes were analyzed in core BT2)

Fig. 6 Total hydrocarbon concentration (HC) and their ratios in Lake Bhimtal sediments (CPI - Carbon Preference Index, TAR - Terrestrial Aquatic Ratio)

Fig. 7 Distribution of specific pigments $(\mathrm{Chl} a, \mathrm{Chl} b$, total carotene, $\beta, \beta$-carotene, zeaxanthin, echinenone, and lutein) and ratios $(\mathrm{Chl} a / \beta, \beta$-carotene, zeaxanthin $/ \beta, \beta$ carotene, and echinenone/zeaxanthin) in Lake Bhimtal sediments. Ratios are not indicated below $25 \mathrm{~cm}$ because concentration of $\beta, \beta$-carotene is too low or below the instrument detection limit 
Fig. 1

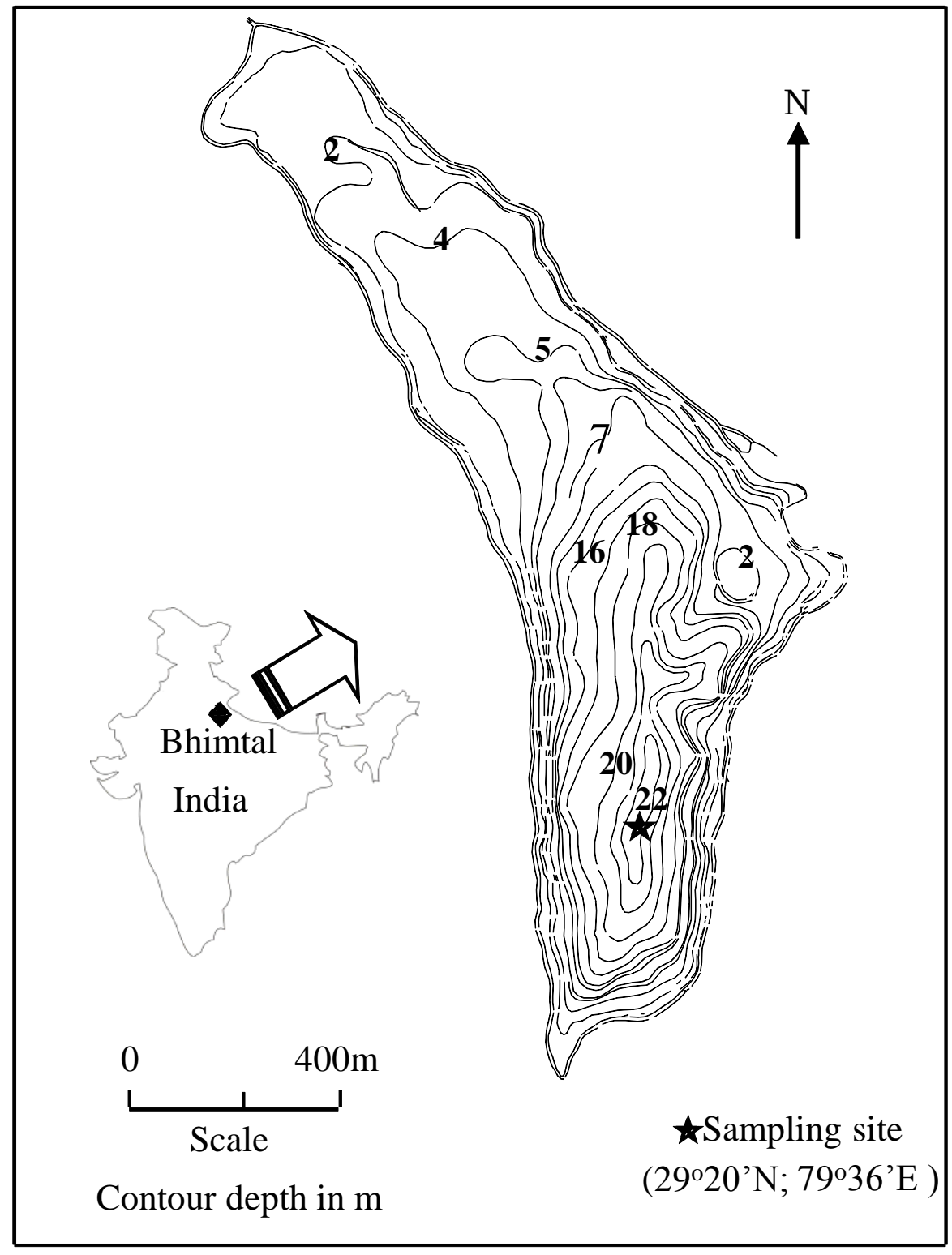


Fig. 2
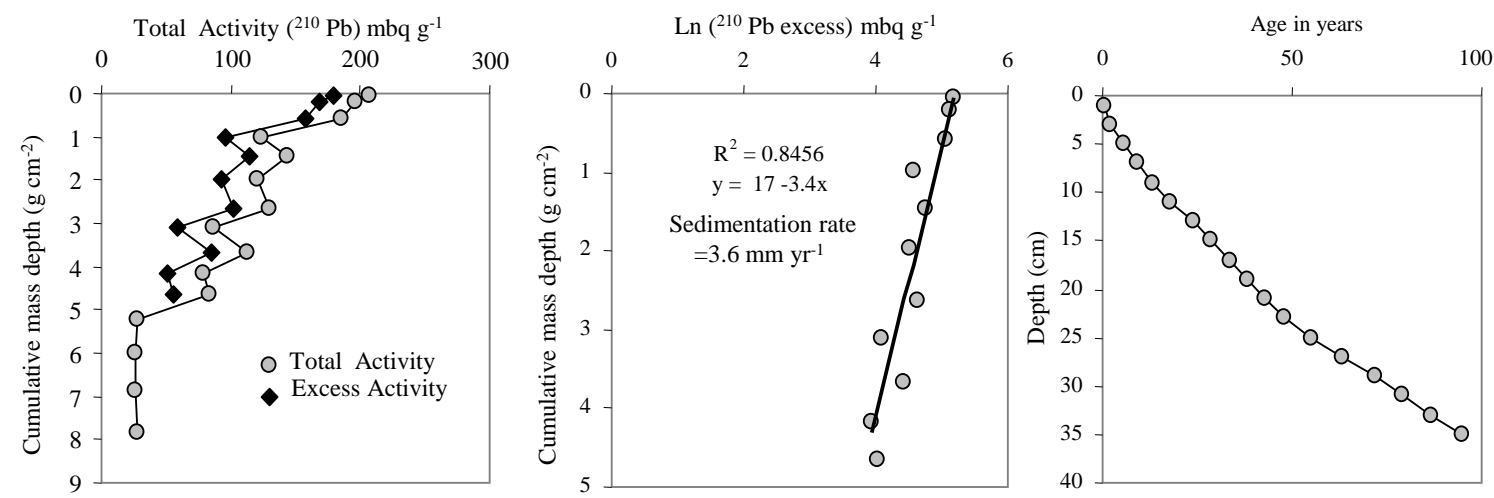
Fig. 3
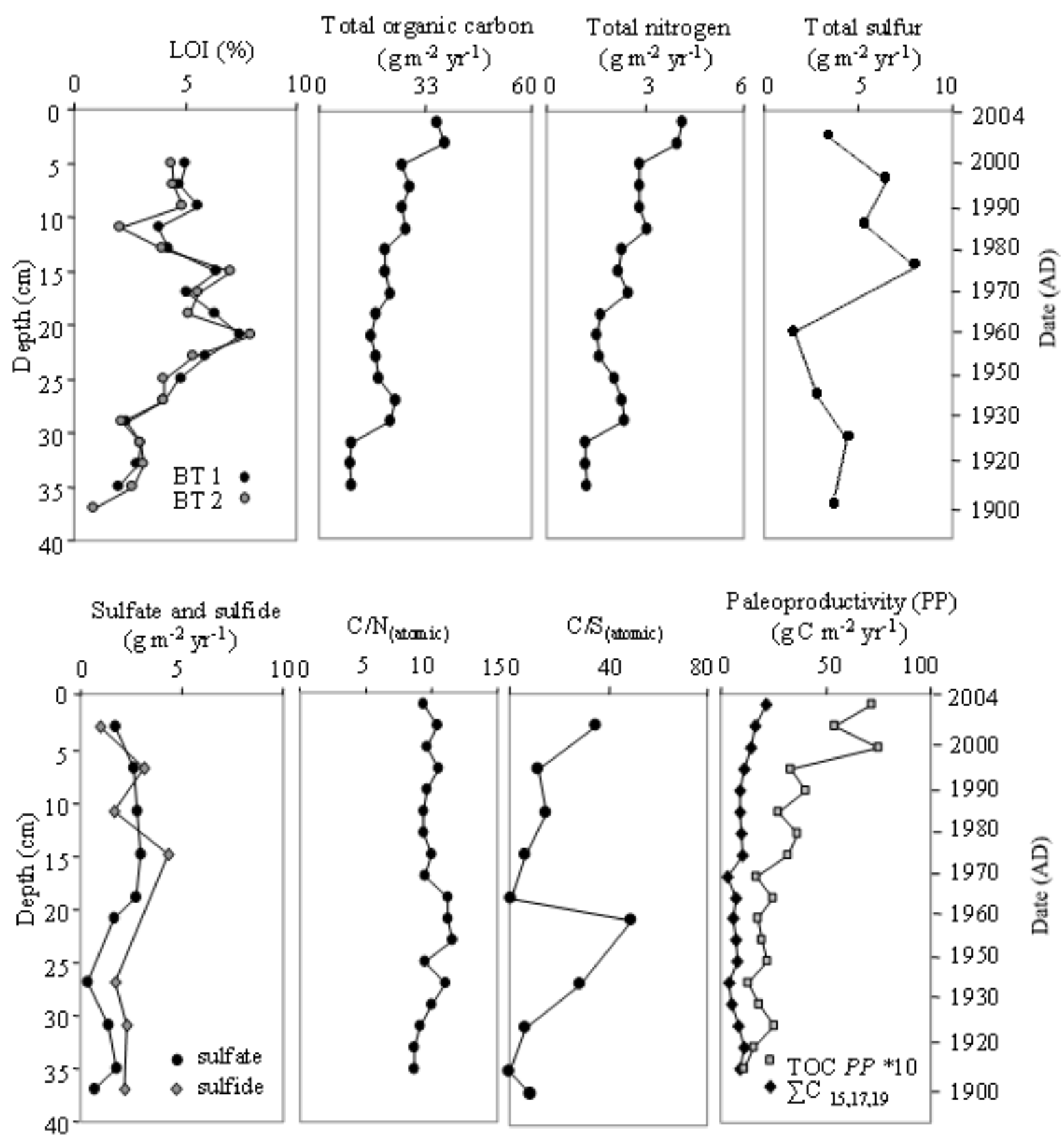
Fig. 4

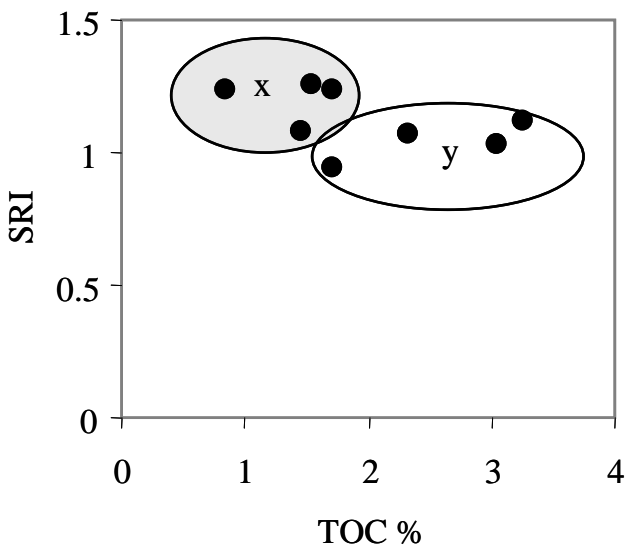


Fig. 5

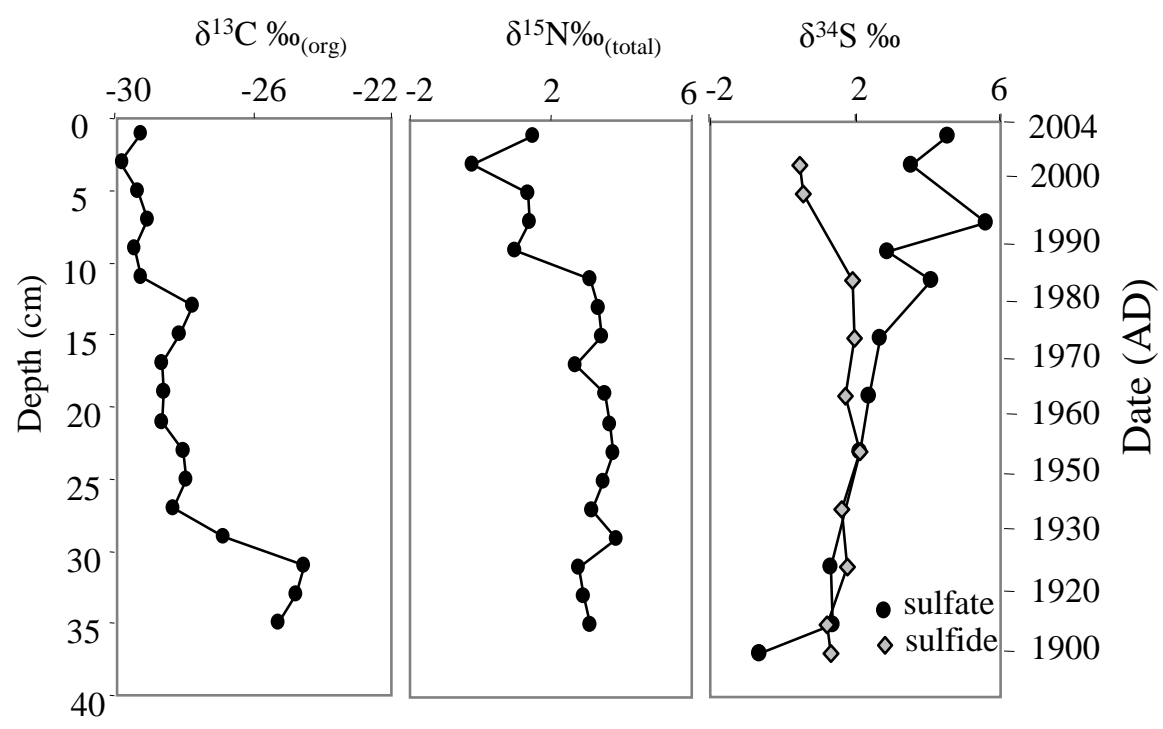


Fig. 6

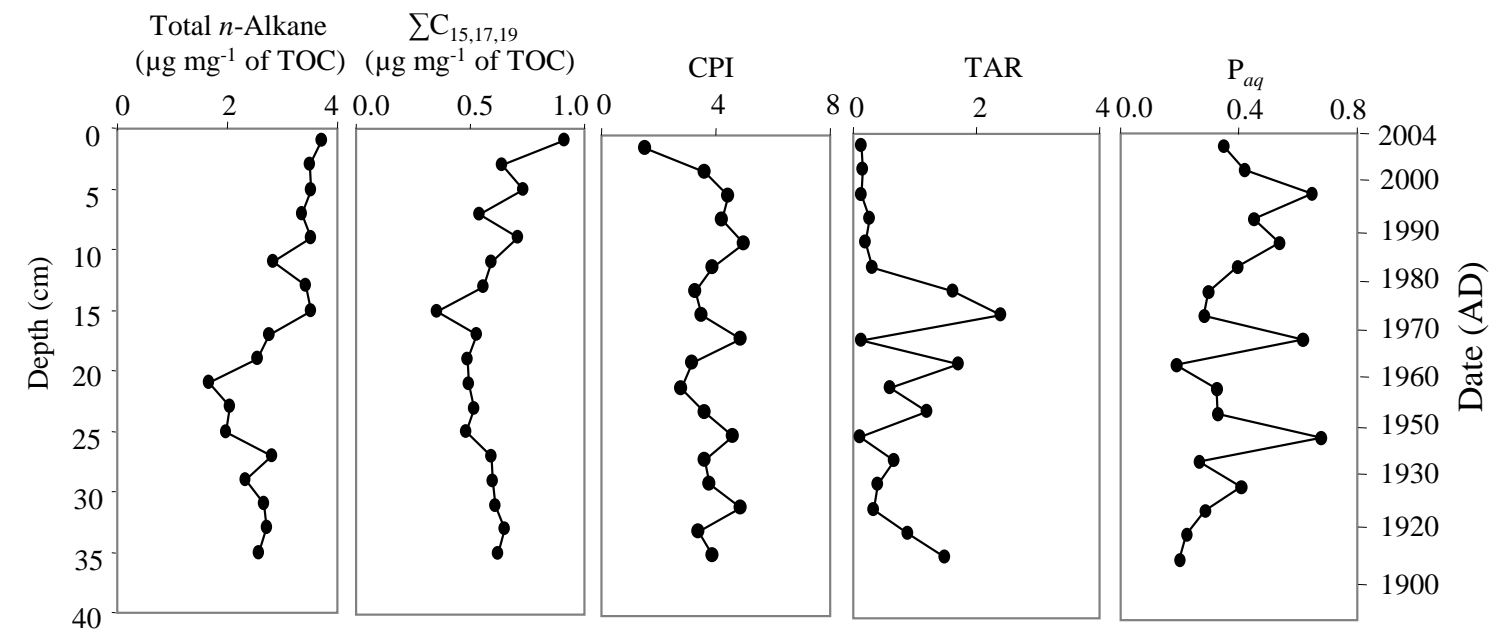


Fig. 7
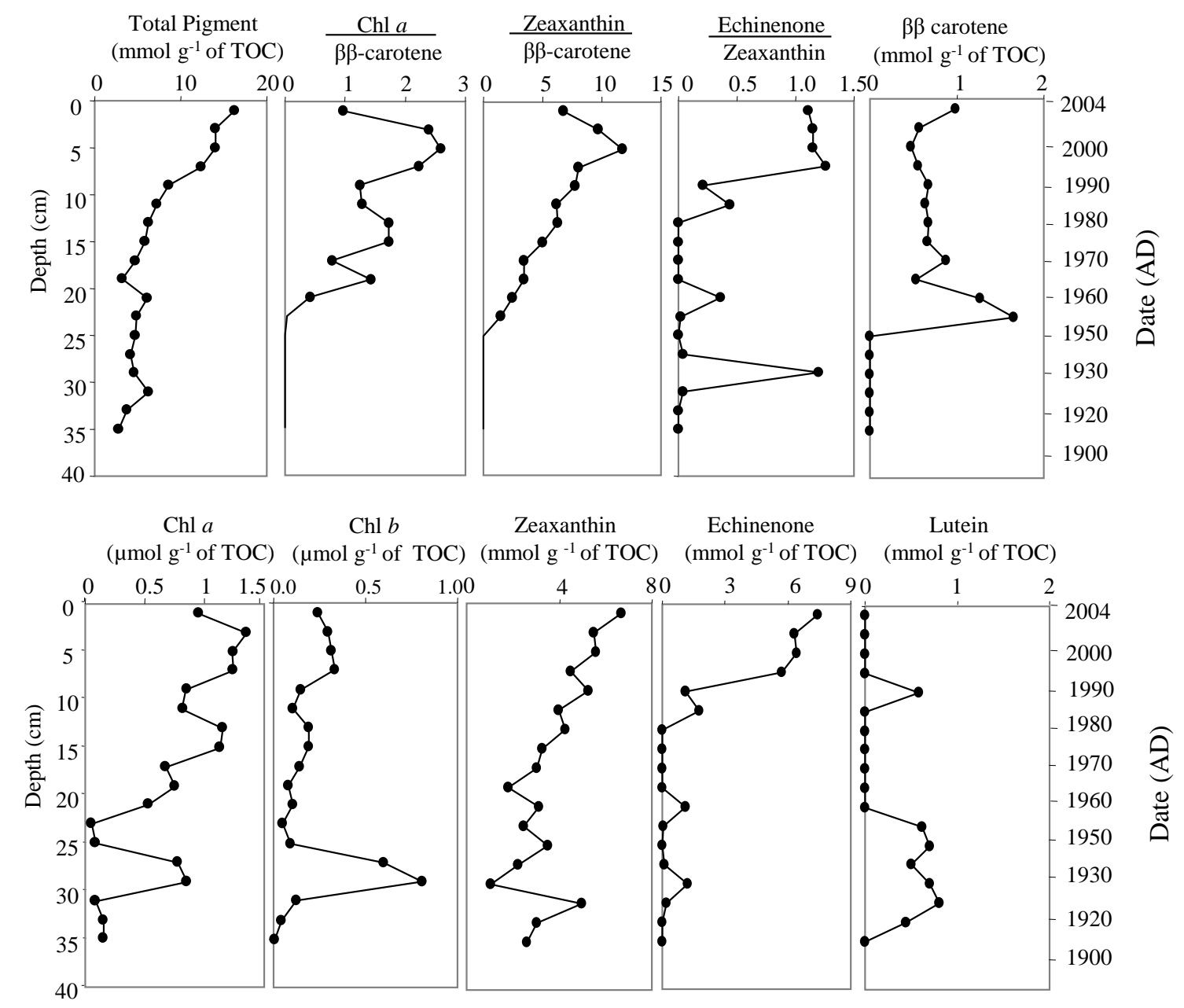